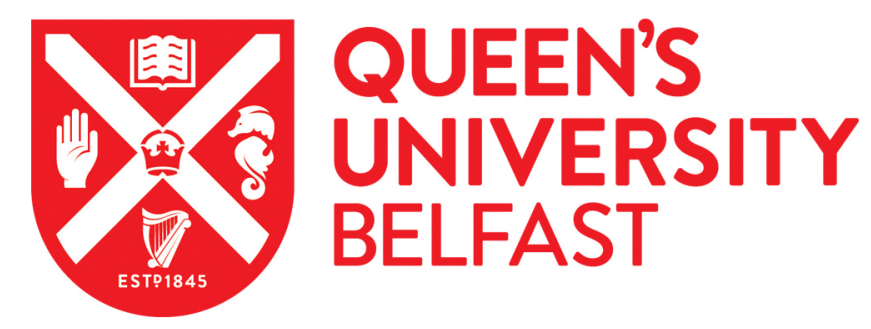

\title{
Homelessness Among Youth Who Identify As LGBTQ+: A Systematic Review
}

Brown, M., \& Mccann, E. (2019). Homelessness Among Youth Who Identify As LGBTQ+: A Systematic Review. Journal of Clinical Nursing. https://doi.org/10.1111/jocn.14818

Published in:

Journal of Clinical Nursing

Document Version:

Peer reviewed version

Queen's University Belfast - Research Portal:

Link to publication record in Queen's University Belfast Research Portal

Publisher rights

Copyright 2019 Wiley. This work is made available online in accordance with the publisher's policies. Please refer to any applicable terms of use of the publisher.

\section{General rights}

Copyright for the publications made accessible via the Queen's University Belfast Research Portal is retained by the author(s) and / or other copyright owners and it is a condition of accessing these publications that users recognise and abide by the legal requirements associated with these rights.

Take down policy

The Research Portal is Queen's institutional repository that provides access to Queen's research output. Every effort has been made to ensure that content in the Research Portal does not infringe any person's rights, or applicable UK laws. If you discover content in the Research Portal that you believe breaches copyright or violates any law, please contact openaccess@qub.ac.uk. 
HOMELESSNESS AMONG YOUTH WHO IDENTIFY AS LGBTQ+: A SYSTEMATIC REVIEW

\author{
Concise title: Homeless LGBT+ youth review
}

\title{
Authors:
}

Edward McCann PhD RN RPN RNT FHEA FEANS

Assistant Professor, School of Nursing and Midwifery, University of Dublin, Trinity College, Dublin, Ireland.

Email: mccanned@tcd.ie

Tel: +35318964161

Michael Brown PhD RGN RNLD SFHEA FRCN

Professor of Nursing, School of Nursing and Midwifery, Queen's University Belfast, Northern Ireland, United Kingdom

Email: m.j.brown@qub.ac.uk

\section{Correspondence:}

Dr Edward McCann

Trinity College Dublin

School of Nursing and Midwifery

24 D'Olier Street

Dublin 2

Ireland

E-mail: mccanned@tcd.ie

Phone: +35318964161

\section{Author contributions:}

EM and MB designed the review, conducted searches, critical appraisal and analysis of the data. Both authors reviewed drafts and prepared and finalised the review for publication. 


\section{ABSTRACT}

Aims and objectives. To explore homelessness among lesbian, gay, bisexual, transgender, queer/questioning plus (LGBTQ+) youth and to identify their support and care requirements.

Background. LGBTQ+ youth face many health and societal challenges including issues related to homelessness.

Design. A systematic review of qualitative, quantitative and mixed methods studies.

Methods. A search of relevant electronic databases was carried out and included the dates August 2008- August 2018 and limited to academic journals and peer reviewed empirical studies written in English. Included studies specifically addressed the homeless experiences of youth aged 13-24 years old who identified as LGBTQ+. The PRISMA checklist was used in the review. A quality assessment instrument was used to review all of the selected papers and narrative methods utilised in the synthesis of the research evidence.

Results. The search resulted in 319 papers and after applying distinct inclusion criteria, a total of 14 papers were considered suitable for the systematic review. Following analysis, the four main themes identified were stigma, discrimination and exclusion, mental health issues and substance use, sexual risks and vulnerability, and interventions and supports.

Conclusions. LGBTQ + youth homelessness is a major public health concern that has significant consequences for a young person's physical and psychosocial well-being.

Relevance to clinical practice. Practitioners need to be aware of the specific health and support requirements of LGBTQ+ youth in relation to homelessness. Inclusive and holistic care plans should exist that are fully responsive to the distinct needs of this group guided by definitive policies and sound clinical research. The implications for future nursing practice are presented and discussed.

\section{Keywords:}

Homelessness; literature review; youth; LGBTQ; health risks; social exclusion; nursing practice 


\section{What does this paper contribute to the wider global clinical community?}

- Highlights key physical and psychosocial issues for homeless youth whom identify as LGBTQ+

- Evidences the growing and evolving research focusing on LGBTQ+ youth homelessness concerns

- Sets out nursing responses, potential supports and interventions and service developments for LGBTQ+ homeless youth.

\section{INTRODUCTION}

Individuals have specific physical health, mental health and substance use needs however, many can face barriers when seeking access to appropriate supports and services. Homeless LGBTQ+ youth often have no fixed abode and no money, endure family conflict, may be kicked out of their family home, and may have to withstand hostilities related to stigma, discrimination and negative societal attitudes.

Worldwide, homelessness is a growing concern and there is an established body of literature that investigates the phenomena in the general youth homeless population (Edidin et al. 2012, Grant et al. 2013, Curry et al. 2017, McIntyre et al. 2017, Moyer 2017, Steen and MacKenzie 2017, Vitopoulos et al. 2017, Morton et al. 2018). Youth homelessness has been defined by Gaetz et al. 2013) as:

Youth aged 13-24 who are living independently of parents and/or caregivers and lack social supports necessary for transition from childhood to adulthood. They do not have a stable or consistent source of income or place of residence, nor do they necessarily have adequate access to support networks to foster a safe and nurturing transition into the responsibilities of adulthood.

Homelessness can include people who are living on the streets, in emergency shelters or temporary accommodation, for example, couch surfing, a vehicle and squatting. 
Furthermore, a home may be perceived as more than a physical space; it is a place that provides roots, identity, security and a sense of belonging and emotional wellbeing (Crisis 2018).

In recognizing and being fully inclusive of relevant sexual and gender characteristics, the umbrella term LGBTQ+ (lesbian, gay, bisexual, transgender, queer/questioning, plus) is applied throughout this paper (Formby 2017, McCann \& Brown 2018).

Greater interest is now being directed towards the experiences of homeless LGBTQ+ youth and available literature appears to be evolving in this regard (Page 2017, Stablein 2017). Whilst this is an important development, there are still concerns about the availability of appropriate supports and services to address physical, emotional and social care needs in this population (Albert Kennedy Trust 2015, Choi et al. 2015, Mayock and Parker 2017). In terms of social inclusion and social justice, significant disparities continue to exist for LGBTQ+ youth homeless that adversely affects their overall health and wellbeing, and this can potentially continue across the life course (World Health Organisation 2013).

There is an estimated total of 1.7 million people who are currently homeless in the USA (Shelton et al. 2018). Evidence suggests that LGBTQ+ youth have significantly higher risks and levels of homelessness than non-LGBTQ+ youth in the general population (Albert Kennedy Trust 2015, Choi et al 2015). Existing studies estimate LGBTQ+ youth homeless ranging between $8 \%$ and 37\% (Rosa et al. 2001, Gaetz 2004, Fredrick et al. 2011, Tyler et al. 2012, Moskowitz et al. 2013). However, there are difficulties ascertaining the numbers of homeless LGBTQ+ youth due to the absence of national data related to this population. There is also a lack of country-specific representative samples and underreporting due to stigma and discrimination experiences (Durso \& Gates 2012, Abramovich 2013, Tyler et al. 2012, Shelton et al. 2018).

Stigma and discrimination-related experiences can have a serious effect on an individual's sense of safety and well-being and can lead to minority stress (Frost \& Meyer 2009, Meyer 2015). The minority stress model conceptualises LGBTQ+ discriminatory experiences, 
violence and abuse, emotional trauma, internalized shame and resilient features. The model acknowledges that LGBTQ+ people can endure excessive levels of discriminatory experiences that can result in a detrimental effect on psychological and emotional well-being. These factors can have a negative result on how LGBTQ+ youth access and use health services. (Meyer 2015). There are a range of other interrelated and contributory factors that can result in homelessness for this population. Homeless youth who identify as LGBTQ+ can endure distinct harmful experiences such as homophobic bullying and victimisation in school and community settings (Albert Kennedy Trust 2015). A further challenge that LGBTQ+ homeless youth face is family conflict that has been consistently shown to be a major factor leading to homelessness. The negative consequences of 'coming out' to family members and friends can include hostility, abuse, rejection and eventual ejection from the family home (Robinson 2018). This can be detrimental to the young person's wellbeing and can lead to further vulnerabilities and physical and psychosocial risks (Rhoades et al. 2018). There is further risk, following homelessness, of exclusion, social isolation and the possibility of abuse, exploitation and victimisation (Curry et al. 2017). As a consequence of these factors, and fractured family and friendship networks, there is the increased potential for the development of mental health issues, notably depression, anxiety, post-traumatic stress disorder (PTSD), suicidal behaviours and substance misuse (Jackman et al. 2016, Reisner et al. 2016, Cronley \& Evans 2017, Davies \& Allen 2017).

The experiences of LGBTQ+ homeless youth has become a social policy concern in terms of human rights and social justice and inclusion. The detrimental effect on individuals and their families is apparent, with implications for nurses and nursing practice.

\subsection{Aims}

This systematic review of the research evidence aims to highlight the homeless experiences of LGBTQ+ youth and explore issues concerning accessing appropriate services and relevant support needs. 


\section{METHODS}

\subsection{Review questions}

1. What are the experiences of homeless LGBTQ+ youth?

2. What are the support and care requirements of LGBTQ+ youth?

\subsection{Ethics statement}

The study is a systematic review of published research evidence therefore ethical approval was not required.

\subsection{Search and selection strategy}

This review identified academic papers that used quantitative, qualitative or mixed methods approaches. A subject Librarian assisted with the literature searching. The databases searched were PsycINFO, CINAHL, MEDLINE, and Sociological Abstracts. The search terms used were: homeless* AND gay OR lesbian* OR bisex* OR transgender* OR queer OR Intersex AND youth* OR adolescent*. The search strategy used in one of the electronic databases is contained in Table 1.

Table 1: CINAHL search strategy

\begin{tabular}{|l|l|}
\hline $\begin{array}{l}\text { Search } \\
\text { code }\end{array}$ & Query \\
\hline S1 & Homeless* \\
\hline S2 & Lesbian* \\
\hline S3 & Bisex \\
\hline S4 & Transgender* \\
\hline S5 & Gay \\
\hline S6 & Queer \\
\hline S7 & Intersex* \\
\hline S8 & Youth \\
\hline S9 & Adolescent* \\
\hline S10 & S2 OR S3 OR S4 OR S5 OR S6 OR S7 \\
\hline S11 & S8 OR S9 \\
\hline S12 & S1 AND S10 AND 11 \\
\hline S13 & $\begin{array}{l}\text { Limiters: English, academic papers, years } \\
\text { 2008-2018 }\end{array}$ \\
\hline
\end{tabular}


The data were published from August 2008 to August 2018. The inclusion criteria were limited to academic journals and peer reviewed empirical studies written in English. People outside of this age range and studies that focused on non-LGBTQ+ homeless youth were excluded. Included studies specifically addressed the homeless experiences of youth aged 13-24 years old who identified as LGBTQ+ and those that did not meet the criteria were rejected. Reasons for exclusion were wrong population, wrong ages, wrong phenomena and wrong language.

A diagram showing the search results PRISMA (Moher et al. 2015) is presented in Figure 1. The PRISMA checklist was used to guide the review process (see Supplementary File 1).

Figure 1: PRISMA Flow Diagram with search results

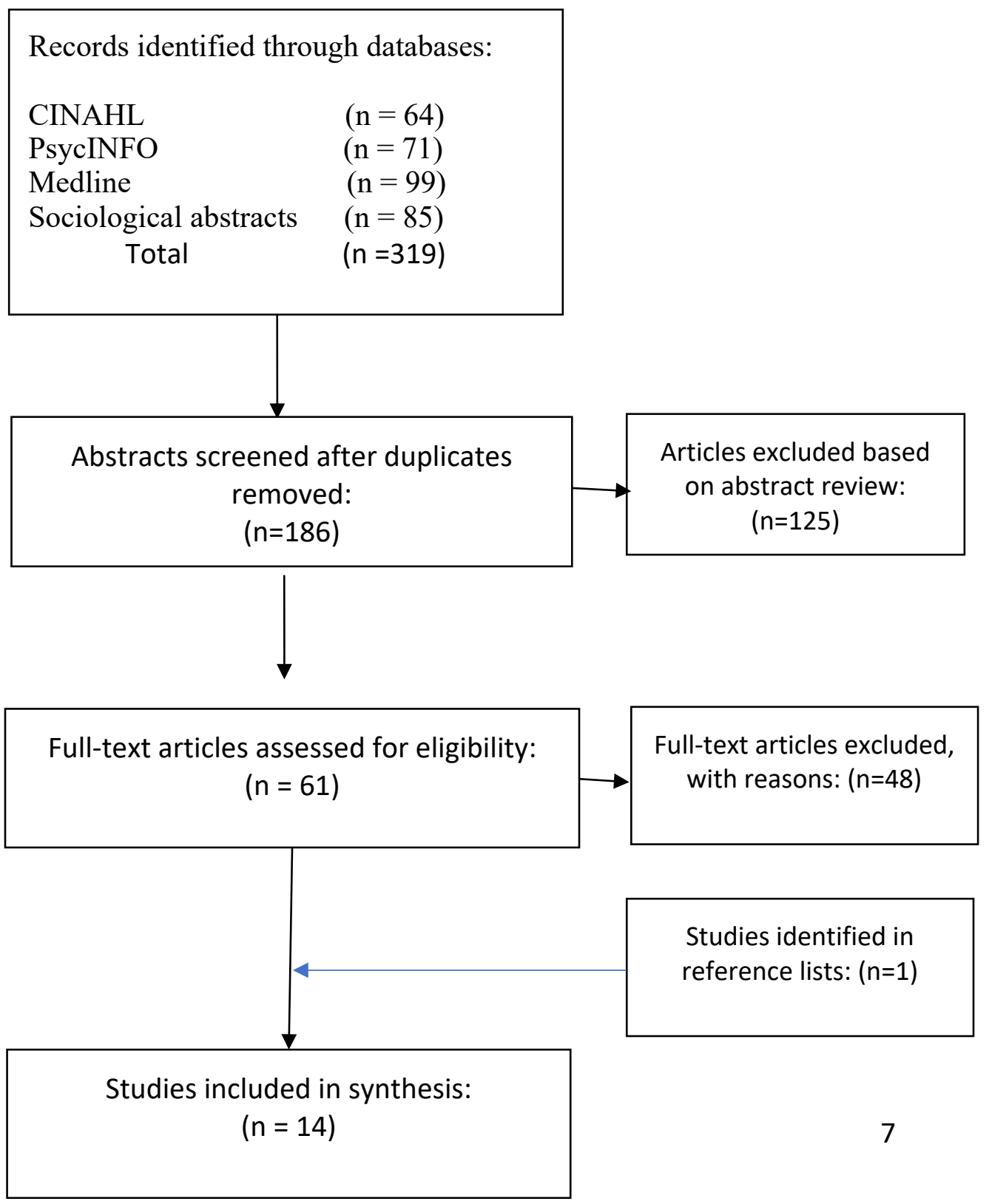




\subsection{Quality assessment}

A quality assessment instrument, the Critical Appraisal Skills Programme (CASP) was used to review all of the selected papers. (Critical Appraisal Skills Programme, 2013). Specific questions were systematically used to appraise the evidence in each of the studies (Table 2). Individual questions were scored zero, one or two out of a potential score of 20. A score of zero was assigned to study with no information, a moderate amount of information scored one, and a question that was comprehensively addressed scored a maximum of two points (Rushbrooke, Murray \& Townsend 2014).

Papers demonstrating high quality overall, with a score of 17 or more, was achieved by a total of 10 of the studies (Reck 2009, Hein 2011, Rosario et al. 2012, Tucker et al. 2012, Gattis 2013, Rice et al. 2013, Tyler 2013, Bruce 2014, Rice et al. 2015). A total of 4 studies achieved a moderate score of between 14 and 16 (Gangamma et al. 2008, Corliss et al. 2011, Bidell 2014, Castellanos 2016). The main reasons for these lower quality assessment scores included limited detail regarding the statement of aims of the study, recruitment strategy, ethical considerations, research relationships and data analysis. No papers were excluded following quality appraisal. 
Table 2: Quality assessment scores $(\mathrm{n}=14)$

\begin{tabular}{|c|c|c|c|c|c|c|c|c|c|c|c|c|c|c|}
\hline & $\begin{array}{l}\text { Bidell } \\
\text { (2014) }\end{array}$ & $\begin{array}{l}\text { Bruce } \\
\text { et al. } \\
\text { (2014) }\end{array}$ & $\begin{array}{l}\text { Castellanos } \\
\text { (2016) }\end{array}$ & $\begin{array}{l}\text { Corliss } \\
\text { et al. } \\
\text { (2011) }\end{array}$ & $\begin{array}{l}\text { Gangamma } \\
\text { et al. } \\
\text { (2008) }\end{array}$ & $\begin{array}{l}\text { Gattis } \\
(2013)\end{array}$ & $\begin{array}{l}\text { Hein } \\
(2011)\end{array}$ & $\begin{array}{l}\text { Reck } \\
(2009)\end{array}$ & $\begin{array}{l}\text { Rice } \\
\text { et al. } \\
\text { (2013) }\end{array}$ & $\begin{array}{l}\text { Rice } \\
\text { et al. } \\
\text { (2015) }\end{array}$ & $\begin{array}{l}\text { Rosario } \\
\text { et al. } \\
(2012)\end{array}$ & $\begin{array}{l}\text { Tucker } \\
\text { et al. } \\
\text { (2012) }\end{array}$ & $\begin{array}{l}\text { Tyler } \\
\text { (2013) }\end{array}$ & $\begin{array}{l}\text { Walls } \\
\& \\
\text { Bell } \\
(2011)\end{array}$ \\
\hline $\begin{array}{l}\text { 1. Clear } \\
\text { statement of } \\
\text { aims }\end{array}$ & 2 & 1 & 0 & 1 & 2 & 2 & 2 & 2 & 1 & 2 & 1 & 2 & 2 & 1 \\
\hline $\begin{array}{l}\text { 2. Appropriate } \\
\text { methodology }\end{array}$ & 2 & 2 & 2 & 2 & 2 & 2 & 2 & 2 & 2 & 2 & 2 & 2 & 2 & 2 \\
\hline $\begin{array}{l}\text { 3. Appropriate } \\
\text { research design }\end{array}$ & 2 & 2 & 2 & 2 & 2 & 2 & 2 & 2 & 2 & 2 & 2 & 2 & 2 & 2 \\
\hline $\begin{array}{l}\text { 4. Appropriate } \\
\text { recruitment } \\
\text { strategy }\end{array}$ & 0 & 2 & 1 & 2 & 2 & 2 & 2 & 2 & 2 & 1 & 2 & 2 & 2 & 2 \\
\hline $\begin{array}{l}\text { 5. Appropriate } \\
\text { data collection } \\
\text { methods }\end{array}$ & 2 & 2 & 2 & 2 & 2 & 2 & 2 & 2 & 2 & 2 & 2 & 2 & 2 & 2 \\
\hline $\begin{array}{l}\text { 6. Research } \\
\text { relationships } \\
\text { considered }\end{array}$ & 0 & 0 & 0 & 0 & 0 & 1 & 2 & 2 & 0 & 0 & 0 & 1 & 2 & 2 \\
\hline $\begin{array}{l}\text { 7. Consider } \\
\text { ethical issues }\end{array}$ & 2 & 2 & 2 & 0 & 0 & 2 & 2 & 2 & 2 & 2 & 2 & 2 & 2 & 2 \\
\hline $\begin{array}{l}\text { 8. Rigorous } \\
\text { analysis }\end{array}$ & 2 & 2 & 1 & 2 & 2 & 2 & 2 & 1 & 2 & 2 & 2 & 2 & 2 & 2 \\
\hline $\begin{array}{l}\text { 9. Clear } \\
\text { findings }\end{array}$ & 2 & 2 & 2 & 2 & 2 & 2 & 2 & 1 & 2 & 2 & 2 & 2 & 2 & 2 \\
\hline $\begin{array}{l}10 . \text { Value of } \\
\text { the } \\
\text { research }\end{array}$ & 2 & 2 & 2 & 2 & 2 & 2 & 2 & 1 & 2 & 2 & 2 & 2 & 2 & 2 \\
\hline $\begin{array}{l}\text { Total scores out } \\
\text { of } 20\end{array}$ & 16 & 17 & 14 & 15 & 16 & 19 & 20 & 17 & 17 & 17 & 17 & 19 & 20 & 19 \\
\hline
\end{tabular}

\subsection{Characteristics of the selected studies}

The fourteen studies that addressed the study objectives are shown in Table 3. All of the studies considered in the review were conducted in the United States of America (USA). The sample sizes were from 5 to 2357 participants. A total of 7 studies used quantitative methods (Gangamma et al. 2008, Corliss et al. 2011, Walls and Bell 2011, Rice et al. 2013, Bidell 2014, Bruce et al. 2014, Rice et al. 2015). Qualitative methods were utilised in 4 of the studies (Reck 2009, Tucker et al. 2012, Gattis 2013, Catellanos 2016). Mixed methods were employed in 3 studies (Hein 2011, Rosario 2012, Tyler 2013). The data collection methods used included surveys, questionnaires, interviews and validated measures. The measures used within the relevant studies fell into two main categories; (i) validated measures widely used and recognised in other research studies (ii) those developed for use in specific LGBTQ+ studies. 
Table 3: Papers included in the review $(n=14)$

\begin{tabular}{|c|c|c|c|c|c|c|}
\hline $\begin{array}{l}\text { Citation } \\
\text { and } \\
\text { country } \\
\end{array}$ & Aim & Sample & Methods & Key findings & Recommendations & $\begin{array}{l}\text { CASP } \\
\text { scores }\end{array}$ \\
\hline $\begin{array}{l}\text { Bidell } \\
(2014)\end{array}$ & $\begin{array}{l}\text { Explore emotional } \\
\text { distress in LGBT } \\
\text { homeless youth in } \\
\text { high school }\end{array}$ & $\begin{array}{l}\text { LGBT } \\
\text { homeless } \\
\text { youth }(n=89)\end{array}$ & Survey & $\begin{array}{l}40 \% \text { did not complete } \\
\text { high school. Support not } \\
\text { sought from school staff. } \\
\text { High levels of } \\
\text { psychological distress } \\
\text { identified and harassment } \\
\text { at home. }\end{array}$ & $\begin{array}{l}\text { Further research } \\
\text { required with larger } \\
\text { sample to determine } \\
\text { when and why LGBT } \\
\text { youth become } \\
\text { homeless. More } \\
\text { mental health } \\
\text { research and } \\
\text { intervention studies. }\end{array}$ & 16 \\
\hline $\begin{array}{l}\text { Bruce et al. } \\
(2014) \\
\text { USA }\end{array}$ & $\begin{array}{l}\text { Determine the } \\
\text { effects of minority } \\
\text { stress on } \\
\text { homelessness and } \\
\text { health disparities } \\
\text { in young men }\end{array}$ & $\begin{array}{l}\text { Young gay } \\
\text { men }(n=200)\end{array}$ & $\begin{array}{l}\text { Survey and } \\
\text { measures }\end{array}$ & $\begin{array}{l}\text { Being rejected by family } \\
\text { and made homeless had a } \\
\text { significant effect on } \\
\text { depression symptoms } \\
\text { and regular marijuana } \\
\text { use. }\end{array}$ & $\begin{array}{l}\text { More family and } \\
\text { school interventions } \\
\text { to address sigma and } \\
\text { discrimination. } \\
\text { Training for staff and } \\
\text { develop social } \\
\text { networking sites. }\end{array}$ & 17 \\
\hline $\begin{array}{l}\text { Castellanos } \\
(2016) \\
\text { USA }\end{array}$ & $\begin{array}{l}\text { Explore } \\
\text { homosexuality and } \\
\text { homelessness in } \\
\text { Latino LGBT } \\
\text { youth }\end{array}$ & $\begin{array}{l}\text { Young men } \\
(n=14) \\
\text { Staff }(n=14)\end{array}$ & $\begin{array}{l}\text { Semi- } \\
\text { structured } \\
\text { interviews }\end{array}$ & $\begin{array}{l}\text { Increased homeless after } \\
\text { placement in systems of } \\
\text { care or the result of pre- } \\
\text { existing family conflict } \\
\text { over LGBT status. }\end{array}$ & $\begin{array}{l}\text { Need to further } \\
\text { explore the risk prior } \\
\text { to disclosure in } \\
\text { family already in } \\
\text { conflict to minimise } \\
\text { the risk of } \\
\text { homelessness. }\end{array}$ & 14 \\
\hline $\begin{array}{l}\text { Corliss et } \\
\text { al. }(2011) \\
\text { USA }\end{array}$ & $\begin{array}{l}\text { Explore the } \\
\text { burden of } \\
\text { homelessness } \\
\text { among sexual } \\
\text { minority } \\
\text { adolescents. }\end{array}$ & $\begin{array}{l}\text { Sexual } \\
\text { minority } \\
\text { youth } \\
(\mathrm{n}=599)\end{array}$ & Survey & $\begin{array}{l}25 \% \text { LGB were homeless } \\
\text { and significantly more } \\
\text { likely to be homeless } \\
\text { than heterosexual } \\
\text { students. Increased risk } \\
\text { of homelessness when } \\
\text { living apart from parents } \\
\text { or guardians. Youth } \\
\text { homeless associated with } \\
\text { violence, substance } \\
\text { misuse and mental health } \\
\text { issues. }\end{array}$ & $\begin{array}{l}\text { More research needed } \\
\text { to better understand } \\
\text { the risk and protective } \\
\text { factors and develop } \\
\text { effective } \\
\text { interventions to } \\
\text { prevent homelessness. }\end{array}$ & 15 \\
\hline $\begin{array}{l}\text { Gangamma } \\
\text { et al. } \\
\text { (2008) } \\
\text { USA }\end{array}$ & $\begin{array}{l}\text { Compare HIV risk } \\
\text { among LGB and } \\
\text { heterosexual } \\
\text { young homeless } \\
\text { people. }\end{array}$ & $\begin{array}{l}\text { Homeless } \\
\text { youth } \\
(\mathrm{n}=268)\end{array}$ & $\begin{array}{l}\text { Questionnaires } \\
\text { and measures }\end{array}$ & $\begin{array}{l}\text { LGB youth have greater } \\
\text { HIV risks and more } \\
\text { significant in bisexual } \\
\text { females. Survival sex } \\
\text { linked to predicting } \\
\text { sexual health risks and } \\
\text { higher among all females } \\
\text { and gay men. }\end{array}$ & $\begin{array}{l}\text { Need greater attention } \\
\text { towards preventative } \\
\text { HIV risk } \\
\text { interventions. }\end{array}$ & 16 \\
\hline $\begin{array}{l}\text { Gattis } \\
(2013)\end{array}$ & $\begin{array}{l}\text { Comparison } \\
\text { between sexual } \\
\text { minority youth } \\
\text { and homeless } \\
\text { heterosexual } \\
\text { youths }\end{array}$ & $\begin{array}{l}\text { Sexual } \\
\text { minority } \\
\text { youth }(\mathrm{n}=66) \\
\text { Heterosexual } \\
\text { youth }(\mathrm{n}=81)\end{array}$ & Interviews & $\begin{array}{l}\text { Statistically significant } \\
\text { differences identified } \\
\text { including: stigma, } \\
\text { discrimination, mental } \\
\text { health, substance use and } \\
\text { sexual risk. }\end{array}$ & $\begin{array}{l}\text { Greater supports to } \\
\text { families including } \\
\text { enhancing } \\
\text { communication and } \\
\text { family therapy. More } \\
\text { research needed into } \\
\text { optimal prevention } \\
\text { and interventions. } \\
\text { Supports to exit } \\
\text { homelessness }\end{array}$ & 19 \\
\hline $\begin{array}{l}\text { Hein } \\
(2011) \\
\text { USA }\end{array}$ & $\begin{array}{l}\text { Compare GBT } \\
\text { and heterosexual } \\
\text { male } \\
\text { homelessness }\end{array}$ & $\begin{array}{l}\text { Homeless } \\
\text { males } \\
\text { GBT }(n=23) \\
\text { Heterosexual } \\
(n=47)\end{array}$ & $\begin{array}{l}\text { Interviews and } \\
\text { measures }\end{array}$ & $\begin{array}{l}\text { Over one third of GBT } \\
\text { youth were homeless due } \\
\text { to identity. Highest were } \\
\text { trans youth. Gay and } \\
\text { trans were younger and } \\
\text { stayed with friends and } \\
\text { families. Hetero and } \\
\text { bisexual youth stayed in } \\
\text { shelters. }\end{array}$ & $\begin{array}{l}\text { Implications for } \\
\text { nursing regarding } \\
\text { policy decisions and } \\
\text { services need full } \\
\text { consideration. }\end{array}$ & 20 \\
\hline $\begin{array}{l}\text { Reck } \\
(2009) \\
\text { USA }\end{array}$ & $\begin{array}{l}\text { Explore } \\
\text { homelessness in } \\
\text { gay and trans } \\
\text { young people of }\end{array}$ & $\begin{array}{l}\text { Gay and } \\
\text { trans people } \\
(n=5)\end{array}$ & Interviews & $\begin{array}{l}\text { More evidence of } \\
\text { experiences related to } \\
\text { invisibility, harassment, } \\
\text { sexualization and } \\
\text { exploitation. }\end{array}$ & $\begin{array}{l}\text { There needs to be } \\
\text { greater community } \\
\text { networks and } \\
\text { supports for homeless } \\
\text { youths. }\end{array}$ & 17 \\
\hline
\end{tabular}




\begin{tabular}{|c|c|c|c|c|c|c|}
\hline & $\begin{array}{l}\text { colour in the } \\
\text { Castro area. }\end{array}$ & & & & & \\
\hline $\begin{array}{l}\text { Rice et al. } \\
(2013) \\
\text { USA }\end{array}$ & $\begin{array}{l}\text { Explore } \\
\text { homelessness, } \\
\text { sexual orientation } \\
\text { and sexual risk } \\
\text { taking among high } \\
\text { school students. }\end{array}$ & $\begin{array}{l}\text { High school } \\
\text { students } \\
(n=1839) \\
\text { LGBTQ } \\
(n=211)\end{array}$ & $\begin{array}{l}\text { Survey and } \\
\text { measures }\end{array}$ & $\begin{array}{l}\text { LGBTQ youth are more } \\
\text { likely to be homeless, } \\
\text { living with a stranger and } \\
\text { less likely to stay in a } \\
\text { shelter. Those staying in } \\
\text { shelters or public spaces } \\
\text { were more likely to } \\
\text { engage in unprotected } \\
\text { sex. }\end{array}$ & $\begin{array}{l}\text { Homelessness and } \\
\text { sexual risk- taking } \\
\text { reduction } \\
\text { programmes need to } \\
\text { be in place. }\end{array}$ & 17 \\
\hline $\begin{array}{l}\text { Rice et al. } \\
(2015) \\
\text { USA }\end{array}$ & $\begin{array}{l}\text { Examine } \\
\text { homelessness and } \\
\text { sexual identity } \\
\text { among middle } \\
\text { school students. }\end{array}$ & $\begin{array}{l}\text { Heterosexual } \\
\text { students } \\
(n=25,903) \\
\text { LGBQ } \\
(n=2357)\end{array}$ & $\begin{array}{l}\text { Survey and } \\
\text { measures }\end{array}$ & $\begin{array}{l}\text { LGBQ students more } \\
\text { likely to be homeless } \\
\text { than heterosexual } \\
\text { counterparts. Higher risk } \\
\text { behaviours, riskier } \\
\text { locations (with stranger) } \\
\text { and less likely to stay in } \\
\text { a youth shelter. }\end{array}$ & $\begin{array}{l}\text { Schools need to have } \\
\text { homelessness } \\
\text { surveillance systems } \\
\text { to reduce poor } \\
\text { physical and mental } \\
\text { health issues and } \\
\text { prevent long-term } \\
\text { homelessness. }\end{array}$ & 17 \\
\hline $\begin{array}{l}\text { Rosario et } \\
\text { al. }(2012) \\
\text { USA }\end{array}$ & $\begin{array}{l}\text { Explore risk } \\
\text { factors for } \\
\text { homelessness } \\
\text { among LGB } \\
\text { youth. }\end{array}$ & $\begin{array}{l}\text { LGB youth } \\
(n=156)\end{array}$ & $\begin{array}{l}\text { Interviews and } \\
\text { measures }\end{array}$ & $\begin{array}{l}48 \% \text { reported ever being } \\
\text { homeless. Most sexually } \\
\text { active and involve in } \\
\text { substance use before } \\
\text { being homeless. Sexual } \\
\text { abuse related to } \\
\text { homelessness. }\end{array}$ & $\begin{array}{l}\text { Interventions required } \\
\text { to support youth in } \\
\text { their sexual } \\
\text { orientation and } \\
\text { prevent or address } \\
\text { sexual abuse issues. }\end{array}$ & 17 \\
\hline $\begin{array}{l}\text { Tucker et } \\
\text { al. }(2012) \\
\text { USA }\end{array}$ & $\begin{array}{l}\text { Examine social } \\
\text { networks and } \\
\text { sexual risk } \\
\text { behaviours in } \\
\text { homeless young } \\
\text { men who have sex } \\
\text { with men (MSM). }\end{array}$ & $\begin{array}{l}\text { MSM } \\
(n=121)\end{array}$ & Interviews & $\begin{array}{l}\text { Good social network less } \\
\text { likely to engage in } \\
\text { unprotected sex and to } \\
\text { have less sexual partners. } \\
\text { Risks associated with } \\
\text { older age, Hispanic } \\
\text { ethnicity, lower } \\
\text { education, depression, } \\
\text { less positive condom } \\
\text { attitudes and } \\
\text { homelessness. }\end{array}$ & $\begin{array}{l}\text { HIV prevention } \\
\text { programmes need to } \\
\text { be multi-pronged } \\
\text { including expanding } \\
\text { social networks, } \\
\text { effective condom use } \\
\text { and access to mental } \\
\text { health and housing } \\
\text { services. }\end{array}$ & 19 \\
\hline $\begin{array}{l}\text { Tyler } \\
(2013) \\
\text { USA }\end{array}$ & $\begin{array}{l}\text { Explore homeless } \\
\text { youth HIV risk } \\
\text { behaviours and } \\
\text { social networks. }\end{array}$ & $\begin{array}{l}\text { Homeless } \\
\text { youth } \\
(\mathrm{n}=249) \\
\text { GLBT } \\
(\mathrm{n}=50)\end{array}$ & $\begin{array}{l}\text { Interviews and } \\
\text { measures }\end{array}$ & $\begin{array}{l}\text { GLBT youth aged 19-21 } \\
\text { years who had run away } \\
\text { from home engaged in } \\
\text { more HIV risk } \\
\text { behaviours with } \\
\text { strangers. }\end{array}$ & $\begin{array}{l}\text { Need to identify risk } \\
\text { factors including } \\
\text { problematic social } \\
\text { networks to minimise } \\
\text { the risk of STIs and } \\
\text { HIV. }\end{array}$ & 20 \\
\hline $\begin{array}{l}\text { Walls \& } \\
\text { Bell (2011) } \\
\text { USA }\end{array}$ & $\begin{array}{l}\text { Examine survival } \\
\text { sex in homeless } \\
\text { youth }\end{array}$ & $\begin{array}{l}\text { Homeless } \\
\text { youth } \\
(\mathrm{n}=1625) \\
\text { GLB } \\
(\mathrm{n}=325)\end{array}$ & $\begin{array}{l}\text { Survey and } \\
\text { measures }\end{array}$ & $\begin{array}{l}\text { African American, GLB } \\
\text { and HIV +ve youth more } \\
\text { likely to engage in } \\
\text { survival sex. }\end{array}$ & $\begin{array}{l}\text { Need to openly } \\
\text { discuss survival sex. } \\
\text { Education and } \\
\text { intervention } \\
\text { programmes needed } \\
\text { to minimise risks. }\end{array}$ & 19 \\
\hline
\end{tabular}

\subsection{Data extraction and analysis}

One of the most rigorous approaches is a meta-analysis of research studies, which was the primary intention of this review. Following the identification and analysis of the papers that met the aims of the review, a meta-analysis was deemed inappropriate. This was due to the varying sampling methods and sample sizes, the research designs adopted across the 
studies, and the widely contrasting methodological approaches employed. As a consequence, a narrative synthesis was selected as the most appropriate method as it relies on the identification of key words and text to summarise and explain the findings from the included studies (Popay et al. 2006). Thematic analysis of the data was conducted. The relevant themes were identified across all of the studies and codes applied to the data. Contrasts and comparisons were made between studies following the grouping of concepts. The themes were identified individually by members of the research team. They were then collectively discussed, verified and approved by the research team, thereby minimising the potential of reviewer bias (Caldwell et al. 2011).

\section{RESULTS}

Following a critical analysis of the studies, the four main themes identified were (i) stigma, discrimination and exclusion (ii) mental health issues and substance use (iii) sexual risks and vulnerability (iv) interventions and supports.

\section{Stigma, discrimination and exclusion}

Homeless youth who identify as LGBTQ+ continue to be one of the most marginalized and disenfranchised groups in society. Nevertheless, the multifarious pathways to homelessness in LGBTQ+ youth remains understudied (Gangamma et al. 2008, Tucker et al. 2012). The limited available international evidence reveals that homelessness figures are significantly higher in this group than in the general youth population (Gattis 2013, Rice et al. 2013, Tyler 2013). From a practice viewpoint, there is an increased interest in issues related to trauma, stigma, discrimination and social exclusion and their effects on young LGBTQ+ people (Corliss 2011, Bidell 2014, Bruce et al. 2014). The experiences of minority stress, including heterosexist attitudes and reactions, can have a profound effect on young people who identify as LGBTQ+ as they seek to affirm their sexual identity (Bruce et al. 2014). Identified stressors for LGBTQ+ youth, such as those associated with stigma and discrimination, can result in greater physical and mental health concerns, including risky sexual behaviour and substance 
misuse. These factors may contribute significantly to the LGBTQ+ youth homeless figures (Corliss et al 2011, Castellanos 2016). The cumulative effect of negative psychosocial experiences can lead to greater instances of depression and suicidal behaviours (Bruce et al. 2014). Extreme family conflict concerning the disclosure of sexual orientation and the process of familial disintegration can increase the risk of rejection and result in homelessness (Castellanos 2016). One study, that investigated homeless LGBTQ+ youth of colour, described participants' experiences of developing resilience and finding safety, security and support in gay-friendly districts and social spaces (Reck 2009). Although exclusion, discrimination and victimisation are important contributory influences on LGBTQ+ youth homelessness, more research is required to determine the relevant risk and protective characteristics and to identify effective strategies and interventions to address the pertinent issues and concerns (Corliss et al. 2011, Hein 2011).

\section{Mental health issues and substance use}

The effects of living in heteronormative environments and experiencing negative societal reactions, such as discrimination, stigma and victimization, can result in significant mental health issues, including depression, self-harm and substance use (Tucker et al. 2012, Bidell 2014, Gattis 2013, Rice et al. 2013). Substance use is more prevalent and is experienced at a younger age by lesbian, gay and bisexual (LGB) youth homeless compared to LGB youth who were not homeless (Rosario et al. 2012). Significant levels of emotional and psychological distress, related to harassment at home, were discovered to be a key factor towards increased drop-out rates in LGBTQ+ high school graduates, with almost $40 \%$ of LGBTQ+ homeless youth failing to complete high school (Bidell 2014). High school LGBTQ+ students were more likely to find themselves in more risky situations, with a stranger, for example, than seeking out the relative safety of a youth shelter. Substance use was perceived as a key issue in contributing to homeless LGBTQ+ youth, with homeless LGBTQ+ youth more likely than homeless heterosexual youth to have used substances (Gattis 2013). A study examined social 
support and its impact upon homeless LGBTQ+ youth and pinpointed the development of interventions that address specific psychosocial challenges, risk and vulnerability factors, such as mental health and substance use issues (Rosario et al. 2012). Schools and colleges are encouraged to mobilise surveillance strategies to identify early detection of homelessness and implement responsive support services to address possible psychosocial issues and concerns (Rice et al. 2015).

\section{Sexual risks and vulnerability}

In addition to increased vulnerability and susceptibility to physical health issues, such as respiratory diseases, existing studies report that homeless LGBTQ+ youth engage in more sexual risk activities than non-homeless youth and are increasingly exposed to sexual transmitted infections (STIs) (Gangamma et al. 2008, Tucker et al. 2012, Rice et al. 2013, Tyler 2013). Furthermore, homeless LGBTQ+ youth are more likely to end up staying with strangers and to participate in unprotected sex (Rice et al. 2013). GLB youth have been shown to have greater risks of HIV and rates are significantly higher in bisexual females. Further, survival sex was the greatest predictor of increased sexual health risks (Gangamma et al. 2008). Homeless young gay men were more likely to have fewer sex partners if members of their social network were not heavy drinkers. Other predictors of sexual risk behaviour included lower education, depression, negative attitudes to condom use and sleeping outdoors (Tucker et al. 2012). Young LGBTQ+ people who have frequently run away from home demonstrated significantly higher HIV risk behaviours (Tyler 2013). With few legitimate methods of supporting themselves, many LGBTQ+ youth were forced to engage in survival sex or sex work, where individuals were offered money, drugs, shelter or food in return for sex (Walls \& Bell 2011). Homeless youth who were involved in survival sex were shown to be at greater risk of mental health problems than those who did not engage in sex work, with a significant risk of contracting HIV and STIs (Gangamma et al. 2008). The results of one study suggested that alcohol and methamphetamine use can play a central role in survival sex involvement and effective drug 
screening can identify youth at increased risk of this form of sexual activity (Walls \& Ball 2011). A significant number of studies in the review indicated that appropriate and responsive services need to be in place in order to address the distinct needs of young homeless people whom identify as LGBTQ+ (Gangamma et al. 2008, Rosario et al. 2012, Tucker et al. 2012, Gattis 2013, Rice et al. 2013, Bruce et al. 2014, Rice et al. 2015).

\section{(v) Interventions and supports}

Youth who identify as LGBTQ+ can endure noteworthy challenges in their daily lives that may impact negatively on their physical and psychosocial well-being. Individuals can experience discrimination, victimization, heterosexism, homophobia, biphobia and transphobia (Corliss et al. 2011, Bidell 2014). They have an increased susceptibility to mental illnesses, substance use issues and sexual health concerns (Hein 2011, Castellanos 2016). They may have been subjected to family hostility, violence and abuse, ending up being expelled from the family home (Gattis 2013). Young people may find themselves on the streets, destitute, and forced into prostitution, thus increasing their risk and vulnerabilities (Bruce et al. 2014). Homelessness in LGBTQ+ youth is a crucial issue for health services in assessing for and planning the types of interventions and supports that may be provided for this group. There needs to be clear and specific policies and guidelines that are realistic, responsive and achievable, with strategies in place to tackle stigma and discrimination (Hein 2011). This includes sexual orientation and gender issues which are further compounded by the double stigmatizing effects of homelessness (Bruce et al. 2014). There should be in existence resilience enhancement support programmes and access to relevant personnel that the young person can approach, confide in and trust (Tucker et al. 2012). Mental health concerns, such as anxiety and depression should be acknowledged and access increased to evidence-based talking therapies (Rice et al. 2015). Suitable family psychosocial interventions should be accessible and designed to meet the identified needs of families and carers and help them to address specific challenges (Gattis 2013). Appropriate health services should be non- 
discriminatory, affirming, open and inclusive. Necessary supports and interventions should be available and provided by staff who are culturally competent, knowledgeable and can effectively advocate on behalf of LGBTQ+ youth. Training and education programmes should exist for health practitioners and other professional groups that address the holistic issues related to LGBTQ+ homelessness (Reck 2009, Rice et al. 2013). Schools should instigate surveillance strategies and develop early intervention and prevention services (Rice et al. 2015).

\section{DISCUSSION}

The findings of this review have highlighted key issues and indicates areas requiring further consideration and attention. The implications and relevance of the findings in relation to nurses and nursing practice are significant and have an impact upon policy, practice, education, and future research developments.

As a starting point, government agencies and health surveillance organisations need to collect, collate and disseminate accurate data on the sexual and gender identity of LGBTQ+ youth. This evidence needs to be interrogated and interpreted locally by service providers to develop and implement clear policies and guidelines to ensure there are appropriate and responsive health services that responds to the needs of LGBTQ+ homeless youth (Rice et al. 2013, Tyler 2013, Bidell 2014, Castellanos 2016). Health services need to acknowledge and respond to the specific and significant risks faced by LGBTQ+ homeless youth, for example, exploitation, abuse, family rejection, STI's and mental health problems (Gangamma et al. 2008, Rosario 2012, Gattis 2013, Bruce et al.2014, Rice et al. 2015). All require specific responses and have important service development and delivery implications, including nursing and nurses.

In practice, clinical nurses need to be aware of the unique care and support needs of this group. Holistic nursing assessments must incorporate the full range of health and social care requirements and plans of care should reflect interventions and supports required. Some of the 
key issues and concerns that have emerged from this review relate to stigma, mental health and sexual risk-taking behaviours (Bidell 2014, Bruce et al. 2014, Gattis 2013, Rice et al. 2013). The acceptance of sexual and gender identity, as well as appropriate psychological support was identified as an important need for LGBTQ+ people (Corliss et al. 2011). Clinical nurses are well placed to provide the necessary emotional supports through counselling and psychologically-based treatment approaches. In this review of the research evidence, familybased interventions were deemed fundamental in helping families understand the 'coming out' experience (Gattis 2013). Therefore, it would be necessary from a preventative perspective to assist families coping with conflict, to improve communication and to gain a better understanding of specific perspectives and issues, thus seeking to minimize potential homelessness. Such interventions may also support reconnecting LGBTQ+ youth with their families following estrangement, with a view to enabling an exit from homelessness altogether (Gattis 2013). Statutory and non-statutory organisations need to coordinate their services across sectors to focus on the causes of homelessness by acknowledging and responding to the factors that lead to LGBTQ+ youth homelessness. This includes, education authorities, social work departments, social care services and housing providers working collaboratively with general and LGBTQ+ specific local services to provide holistic healthcare that responds to wider support needs, mental illness, STI's substance and alcohol use and promotes access to education, skills development and employability. Such responses are necessary to provide a comprehensive 'wrap-around' service for LGBTQ+ homeless youth that recognizes and responds to their distinct needs. An organization, the True Colors Fund is an example of collaborative working to address LGBTQ+ homelessness through advocacy, education and training and youth collaboration. The organization provides an online training platform including the True Inclusion Toolbox to assist service providers in developing LGBTQ+ inclusive environments (https://ourtruecolors.org). Another example is the LGBT Youth Homeless Prevention Initiative that involves coordination, collaboration and developing 
support systems including youth shelters and emergency accommodations (US Department of Housing and Urban Development). In the United Kingdom (UK), The Albert Kennedy Trust has an established strategy to address LGBT youth homelessness including their independent living initiative, youth engagement programmes, outreach service and online supports for families (Albert Kennedy Trust 2018).

This systematic review has identified concerns regarding the limited availability of appropriate education and training for service providers (Hein 2011, Wall \& Bell 2011, Bruce et al. 2014). Practitioners, including clinical nurses, need access to education and training around the individual experiences and needs of LGBTQ+ homeless youth, necessary to ensure their practice is person-centred and focused on the needs of the individual and their specific needs and concerns. Such opportunities allow practitioners to gain crucial knowledge and skills, question their own attitudes, values and beliefs, and identify opportunities to address stigma and discrimination, thereby providing responsive and affirmative care. Practitioners need to be supported to understand and appreciate the full extent to the physical, psychological and psychosocial health concerns and the necessary attributes of culturally competent approaches to care (McCann \& Brown 2018). Such developments need to be informed by the most up-to-date research evidence in relation to human rights, social inclusion and reducing health disparities (World Health Organisation 2013, United Nations 2016). There is a need for education, social care and health professionals to come together with other key stakeholders including, the Royal College of Nursing and General Medical Council; global organisations such as the World Health Organisation and United Nations; LGBT specific groups, including Stonewall, Transgender Equality Network and homelessness organisations, such as Albert Kennedy Trust, Centre Point, Focus Ireland. From a European perspective, there has been a limited attention paid to the issue of LGBTQ+ homelessness in the research literature (Mayock \& Parker 2017, Pearce 2017). The main focus to date has been in the US and the Fenway Institute has a well-established track record of tackling LGBTQ+ youth homeless and poverty. 
They provide knowledge and skills training for practitioners from statutory and non-statutory organisations to help them work more effectively in addressing homelessness in LGBTQ+ client groups (Reisner et al. 2015).

This review has highlighted several areas of research that should be conducted to effectively address the support needs of youth homeless who are LGBTQ+. A significant obstacle to effectively addressing LGBTQ+ youth homelessness has been the dearth of data about the prevalence, needs and issues effecting this population. From the findings of this review, it has become more apparent that there is a distinct lack of appropriate research evidence that focuses on key concerns. A significant number of the studies included in the review indicated the need for education and training programmes for service providers from areas such as child welfare, youth justice, homelessness, education, health and mental health systems (Corliss et al. 2011, Gattis 2013, Bruce et al., 2014, Rice et al. 2015). Other studies highlighted the need for education and training initiatives for LGBTQ+ youth that address issues related to mental health, sexuality, physical health, HIV and STIs, survival sex, risk and vulnerability, stigma and discrimination, resilience and developing social networks (Hein 2011, Walls \& Bell 2011, Tucker et al. 2012, Rice 2013, Bidell at al. 2014, Castellanos 2016). There is scope for further research evaluating specific education and training programmes including international multi-centre and longitudinal follow-up studies. There is also an opportunity to conduct transcultural research among sub-populations. The review has revealed distinct gaps in evidence around the views and experiences of homeless LGBTQ+ youth to clearly identify their specific healthcare needs and requirements. Future research studies should also determine the perceptions and experiences of families to establish appropriate family and carer supports. Overall, there is an opportunity to fully explore and understand individual, family and carer perspectives in order that appropriate and responsive supports and services may be developed and made accessible to this group of people. 
This review had several limitations including the distinct lack of research studies carried out beyond the USA, where all the studies were conducted. There are no international multicentred studies or research into the needs of homeless transgender populations. There was also a paucity of longitudinal studies. Future research studies should therefore aim to address the lacunae that exists in the research evidence-base. From the perspective of bias, the authors have been rigorous in the strict application of a narrative synthesis review process. However, it is acknowledged that there may be potential for subjectivity.

\section{CONCLUSION}

This systematic review reveals that youth homelessness remains a significant concern for health and social care services with an increasing number of young homeless people who identify as LGBTQ+. The causes of homelessness among this group, and their need for services and support, are multifaceted and complex and involve physical and psychosocial issues and concerns. This review argues that in order to address pertinent issues and concerns faced by LGBTQ+ youth homeless, coordinated collaborations across the public, private, and non-profit sectors must occur. Clinical nurses are in a key position to influence the types of supports and interventions that are required to meet the distinct needs of this population including tackling discrimination, addressing mental health issues and focusing on vulnerability and risk factors.

\section{RELEVANCE TO CLINICAL PRACTICE}

There are multiple challenges facing LGBTQ+ homeless youth including obtaining shelter, staying in school, earning an income, accessing social supports and health services. For some, their situation is further compounded by conflict at home, violence and abuse, parental drug use, stigma of living in a shelter and minority stress issues. As a consequence of homelessness, there is disruption to education and future academic attainment that leads to a deficiency in skills and training, poor qualifications and reduced employment and earning opportunities. The lives of LGBTQ+ homeless youth can become increasingly risky and 
vulnerable. Services, if they exist at all, can be delayed, fragmented and disconnected. Clinical nurses are in a position to play a pivotal role in meeting the care needs of LGBTQ+ homeless youth. Nurses practicing across all health care settings will come into contact with this oftenvulnerable population. Clinical nurses practicing in primary care, emergency departments, public health, substance use services, disability services, mental health services and school and child health services are part of the frontline services that will come into contact with LGBTQ+ homeless youth. Therefore, they are in a prime position to provide support and facilitate access to wider health, education and social care services and take a lead role in case management and care coordination to enable access to care and services.

Clinical nursing assessments provide the starting point for initial screening and through the use of open and non-judgmental approaches to history-taking, a clear picture of individual circumstances such as family dynamics, home circumstances, social supports, self-care abilities, financial situation, social networks, child protection, health behaviours and mental health can be established. By obtaining this key information, it is possible to start to plan and deliver nursing care and provide support that begins to address concerns related to fear and isolation, vulnerability, exploitation and sexual abuse issues that are common in LGBTQ+ homeless youth. Collaborative working with other health services and the providers of education, social work, social care, housing, child protection and the police is necessary to ensure that there is access to the range of professionals and support services necessary to ensure that needs are comprehensively assessed and met. From the perspective of nursing practice and given the prevalence of unmet physical and mental health needs of this population, clinical nurses have an opportunity to deliver nursing care that may include, contraception, STI screening, psychological support and therapies, family work and substance use treatment.

From a nurse education perspective, there is an opportunity to integrate the needs of LGBTQ+ youths, including those who are homeless, within undergraduate nursing programmes to raise the awareness of their needs of this population and to highlights areas 
where nursing care and support is indicated. From a continuing professional development (CPD) view point, there is an opportunity to integrate the growing and evolving research evidence-base of this population within both nursing and multiagency CPD programmes and bring clinical nurses and other professionals together from different practice areas to share their experience and practices and build supportive professional networks that focuses on the needs of this population. Nurses are well-placed to collaborate with other researchers in building and growing the evidence-base in this under researched area that can inform future developments in nursing practice.

\section{Acknowledgements}

No external funding.

\section{Contributions}

To be added

\section{Conflict of Interest}

No conflict of interest has been declared by the authors 


\section{REFERENCES}

Abramovich, I. A. (2013) No Fixed Address: Young, Queer, and Restless. In. Gaetz, S., O’Grady, B., Buccieri, K., Karabanow, J., \& Marsolais, A. (Eds.), Youth Homelessness in Canada: Implications for Policy and Practice. Toronto: Canadian Homelessness Research Network Press.

Albert Kennedy Trust (2015) LGBT Youth Homelessness: A UK National Scoping of Cause, Prevalence, Response and Outcome. London: Albert Kennedy Trust.

Albert Kennedy Trust (2018) Strategy 2018-2021: Preventing LGBTQ+ youth homelessness, because no young person should have to choose between a safe home and being who they are. London: Albert Kennedy Trust.

Bidell MP (2014) Is there an emotional cost of completing high school? Ecological factors and psychological distress among LGBT homeless youth. Journal of Homosexuality 61(3), 366-381.

Bruce D, Stall R, Fata A. \& Campbell RT (2014) Modeling minority stress effects on homelessness and health disparities among young men who have sex with men. Journal of Urban Health 91(3), 568-580.

Caldwell K, Henshaw I \& Taylor G (2011) Developing a framework for critiquing health research: An early evaluation. Nurse Education Today 31(8), 1-7.

Castellanos, H.D. (2016) The Role of Institutional Placement, Family Conflict, and Homosexuality in Homelessness Pathways Among Latino LGBT Youth in New York City. Journal of Homosexuality, 63(5), 601-632.

Choi, S.K., Wilson, B.D.M., Shelton, J., \& Gates, G. (2015) Serving Our Youth 2015: The Needs and Experiences of Lesbian, Gay, Bisexual, Transgender, and Questioning Youth Experiencing Homelessness. Los Angeles: The Williams Institute with True Colors Fund.

Corliss, H.L., Goodenow, C.S., Nichols, L. and Austin, S.B. (2011) High burden of homelessness among sexual-minority adolescents: findings from a representative Massachusetts high school sample. American Journal of Public Health 101(9), 1683-1689.

Crisis (2018) Homeless knowledge hub. https://www.crisis.org.uk/endinghomelessness/homelessness-knowledge-hub/ Accessed: 12 January 2018.

Critical Appraisal Skills Programme (2013) Ten questions to help you make sense of qualitative research. Critical Appraisal Skills Programme, Oxford.

Cronley, C., \& Evans, R. (2017). Studies of resilience among youth experiencing homelessness: A systematic review. Journal of Human Behavior in the Social Environment, 27(4), 291-310.

Curry, S.R., Morton, M., Matjasko, J.L., Dworsky, A., Samuels, G.M. and Schlueter, D. (2017) Youth homelessness and vulnerability: How does couch surfing fit? American journal of Community Psychology, 60(1-2), pp.17-24. 
Davies, B. R., \& Allen, N. B. (2017) Trauma and homelessness in youth: Psychopathology and intervention. Clinical Psychology Review 54 17-28.

Durso, L.E., \& Gates, G.J. (2012) Serving Our Youth: Findings from a National Survey of Service Providers Working with Lesbian, Gay, Bisexual, and Transgender Youth who are Homeless or At Risk of Becoming Homeless. Los Angeles: The Williams Institute with True Colors Fund and The Palette Fund.

Edidin, J.P., Ganim, Z., Hunter, S.J. and Karnik, N.S. (2012) The mental and physical health of homeless youth: a literature review. Child Psychiatry \& Human Development 43(3), pp.354-375.

Formby E. 2017 How should we 'care' for LGBTQ+ students within higher education? Pastoral Care in Education 35(3):203-20.

Frederick, T.J., Ross, L.E., Bruno, T.L. and Erickson, P.G. (2011) Exploring gender and sexual minority status among street-involved youth. Vulnerable Children and Youth Studies 6(2), 166-183.

Frost DM \& Meyer IH (2009) Internalised homophobia and relationship quality among lesbians, gay men and bisexuals. Journal of Counseling Psychology 56, 97-109.

Gaetz, S. (2004) Safe streets for whom? Homeless youth, social exclusion, and criminal victimization. Canadian Journal of Criminology and Criminal Justice 46(4), 423-456.

Gaetz, S., O'Grady, B., Buccieri, K., Karabanow, J., \& Marsolais, A. (2013). Youth Homelessness in Canada: Implications for Policy and Practice. Ontario: Canadian Homeless Research Network, The Homeless Hub.

Gangamma, R., Slesnick, N., Toviessi, P. and Serovich, J. (2008) Comparison of HIV risks among gay, lesbian, bisexual and heterosexual homeless youth. Journal of Youth and Adolescence 37(4), 456-464.

Gattis, M.N. (2013) An ecological systems comparison between homeless sexual minority youths and homeless heterosexual youths. Journal of Social Service Research 39(1), 38-49.

Grant, R., Gracy, D., Goldsmith, G., Shapiro, A. and Redlener, I.E. (2013) Twenty-five years of child and family homelessness: where are we now? American Journal of Public Health 103(S2), e1-e10.

Hein, L.C. (2011) Survival strategies of male homeless adolescents. Journal of the American Psychiatric Nurses Association 17(4), 274-282.

Jackman K, Honig J \& Bockting W (2016) Nonsuicidal self-injury among lesbian, gay, bisexual and transgender populations: An integrative review. Journal of Clinical Nursing, 25(23-24), 3438-3453.

Mayock, P. and Parker, S. (2017) Living in Limbo: Homeless Young People's Paths to Housing, Dublin: Focus Ireland. 
McCann, E. and Brown, M. (2018) The inclusion of LGBT+ health issues within undergraduate healthcare education and professional training programmes: A systematic review. Nurse Education Today 64, 204-214.

McIntyre, M., Townsend, C. and Cullen, J. (2017) Responding to the needs of homeless Aboriginal and Torres Strait Islander young people with complex disability: The Guddi for Young People. Journal of Social Inclusion 8(2), 81-89.

Meyer IH (2015) Resilience in the study of minority stress and health of sexual and gender minorities. Psychology of Sexual Orientation and Gender Minorities 2(3), 209.

Moher D, Shamseer L, Clarke M, Ghersi D, Liberati A, Petticrew M,..... PRISMA-P Group (2015) Prefered reporting items for systematic review and meta-analysis protocols (PRISMAP) 2015 statement. Systematic Reviews 4(1), 1-9.

Morton, M.H., Dworsky, A., Matjasko, J.L., Curry, S.R., Schlueter, D., Chávez, R. and Farrell, A.F. (2018) Prevalence and correlates of youth homelessness in the United States. Journal of Adolescent Health 62(1), 14-21.

Moskowitz, A., Stein, J.A. and Lightfoot, M. (2013) The mediating roles of stress and maladaptive behaviors on self-harm and suicide attempts among runaway and homeless youth. Journal of Youth and Adolescence 42(7), 1015-1027.

Moyer, E. (2017) Street Life Under a Roof: youth homelessness in South Africa by Emily Margaretten. Africa: The Journal of the International African Institute 87(3), 644-645.

Page, M. (2017) Forgotten Youth: Homeless LGBT Youth of Color and the Runaway and Homeless Youth Act. Northwestern Journal of Law and Social Policy 12(2), 17.

Pearce, L., 2017. Making nurse education LGBT-friendly. Nursing Standard 31 (23), 22-24.

Popay J, Roberts H \& Sowden A (2006) Guidance on the Conduct of Narrative Synthesis in Systematic Reviews: Final Report. ESRC Methods Programme, Swindon.

Reck, J. (2009) Homeless gay and transgender youth of color in San Francisco:"No one likes street kids"-Even in the Castro. Journal of LGBT Youth 6(2-3), 223-242.

Reisner, S.L., Bradford, J., Hopwood, R., Gonzalez, A., Makadon, H., Todisco, D., Cavanaugh, T., VanDerwarker, R., Grasso, C., Zaslow, S. \& Boswell, S.L. (2015) Comprehensive transgender healthcare: the gender affirming clinical and public health model of Fenway Health. Journal of Urban Health, 92(3), 584-592.

Reisner, S. L., White Hughto, J. M., Gamarel, K. E., Keuroghlian, A. S., Mizock, L., \& Pachankis, J. E. (2016) Discriminatory experiences associated with posttraumatic stress disorder symptoms among transgender adults. Journal of Counseling Psychology 63(5), 509.

Rhoades, H., Rusow, J. A., Bond, D., Lanteigne, A., Fulginiti, A., \& Goldbach, J. T. (2018) Homelessness, mental health and suicidality among LGBTQ youth accessing crisis services. Child Psychiatry \& Human Development 1-9.

Rice, E., Barman-Adhikari, A., Rhoades, H., Winetrobe, H., Fulginiti, A., Astor, R., Montoya, J., Plant, A. and Kordic, T. (2013) Homelessness experiences, sexual orientation, and sexual 
risk taking among high school students in Los Angeles. Journal of Adolescent Health 52(6), 773-778.

Rice, E., Petering, R., Rhoades, H., Barman-Adhikari, A., Winetrobe, H., Plant, A., Montoya, J. and Kordic, T. (2015) Homelessness and sexual identity among middle school students. Journal of School Health 85(8), 552-557.

Robinson, B. A. (2018) Conditional families and lesbian, gay, bisexual, transgender, and queer youth homelessness: Gender, sexuality, family instability, and rejection. Journal of Marriage and Family, 80(2), 383-396.

Rosa, C.J.D., Montgomery, S.B., Hyde, J., Iverson, E. and Kipke, M.D. (2001) HIV risk behaviour and HIV testing: A comparison of rates and associated factors among homeless and runaway adolescents in two cities. AIDS Education and Prevention 13(2), 131-148.

Rosario, M., Schrimshaw, E.W. and Hunter, J. (2012) Risk factors for homelessness among lesbian, gay, and bisexual youths: a developmental milestone approach. Children and Youth Services Review 34(1), 186-193.

Rushbrooke, E, Murray, C. \& Townsend, S. (2014) The experiences of intimate relationships by people with intellectual disabilities: A qualitative study. Journal of Applied Research in Intellectual Disabilities 27, 531-541.

Shelton, J., Poirier, J. M., Wheeler, C., \& Abramovich, A. (2018) Reversing erasure of youth and young adults who are LGBTQ and access homelessness services: Asking about sexual orientation, gender identity, and pronouns. Child Welfare 96(2), 1-28.

Stablein, T. (2017) Estimating the status and needs of homeless LGBT adolescents: advocacy, identity, and the dialectics of support. Gender, Sex, and Sexuality Among Contemporary Youth: Generation Sex 23, 23-41.

Steen, A. and MacKenzie, D. (2017) The sustainability of the Youth Foyer Model: a comparison of the UK and Australia. Social Policy and Society 16(3), 391-404.

Tucker, J.S., Hu, J., Golinelli, D., Kennedy, D.P., Green, H.D. and Wenzel, S.L. (2012) Social network and individual correlates of sexual risk behaviour among homeless young men who have sex with men. Journal of Adolescent Health 51(4), 386-392.

Tyler, K.A., Akinyemi, S.L. and Kort-Butler, L.A. (2012) Correlates of service utilization among homeless youth. Children and Youth Services Review 34(7), 1344-1350.

Tyler, K.A. (2013) Homeless youths' HIV risk behaviors with strangers: Investigating the importance of social networks. Archives of Sexual Behavior 42(8), 1583-1591.

United Nations (2016) Homelessness and Human Rights. UN Office of the High Commissioner, Geneva.

US Department of Housing and Urban Development (2016) Review of the LGBTQ Youth Homeless Prevention Initiative Planning Phase. HUD Office of Community Planning and Development, San Francisco. 
Vitopoulos N, Cerswell Kielburger L, Frederick TJ, McKenzie K, Kidd S. (2017) Developing a trauma-informed mental health group intervention for youth transitioning from homelessness. Professional Psychology: Research and Practice 48(6), 499.

Walls, N.E. and Bell, S. (2011) Correlates of engaging in survival sex among homeless youth and young adults. Journal of Sex Research 48(5), 423-436.

World Health Organization (2013) Addressing the Causes of Disparities in Health Service Access and Utilization for Lesbian, Gay, Bisexual and Transgender (LGBT) Persons. WHO, Geneva. 